\title{
MODERN HEALTH WORRIES IN PATIENTS WITH AFFECTIVE DISORDERS. A PILOT STUDY
}

\author{
Anett FREYLER', Péter SIMOR², Renáta SZEMERSZKYํㅜ, Zsuzsanna SZABOLCS ${ }^{1}$, Ferenc KÖTELES ${ }^{3}$ \\ 'Doctoral School of Psychology, Eötvös Loránd University; Institute of Health Promotion and Sport Sciences, \\ Eötvös Loránd University, Budapesł \\ ${ }^{2}$ Institute of Psychology, Eötvös Loránd University, Budapest \\ ${ }^{3}$ Institute of Health Promotion and Sport Sciences, Eötvös Loránd University, Budapest
}

Background - Modern health worries (MHWs) are associated with various indicators of negative affect, conspiracy theories, and paranormal beliefs in healthy individuals. Purpose - The current pilot study aimed to assess MHWs and indicators of negative affect in patients with affective disorders ( $N=66)$, as well as the possible associations between MHWs and paranoid and schizophrenic tendencies.

Results - Compared to somatic patients, psychiatric patients showed higher levels of MHWs, somatosensory amplification, health anxiety, and somatic symptoms. Medium level associations between MHWs and paranoid $(r=0.35, p<0.01)$ and schizophrenic $(r=0.37, p<0.01)$ tendencies were also revealed. Somatosensory amplification $(\beta=0.452, p<0.001)$ and paranoia $(\beta=$ $0.281, p<0.01)$ significantly contributed to MHWs in multiple linear regression analysis $\left(R^{2}=0.323, p<\right.$ 0.001).

Discussion - High (i.e. pathological) levels of negative affect can impact a number of related characteristics. Non-pathological paranoid tendencies might contribute to MHWs. The identification of paranoid tendencies seems to be relevant for the treatment of psychiatric patients exhibiting MHWs.

Conclusion - Patients with affective disorders are characterized by higher levels of modern health worries, health anxiety, and somatosensory amplification. Modern health worries are associated with paranoid tendencies.

Keywords: negative affect, modern health worries, anxiety, depression, paranoia
MODERNKORI EGÉSZSÉGFÉLTÉS SZORONGÁSOS ÉS HANGULATZAVAROS BETEGEK KÖRÉBEN

Freyler A; Péter S; Szemerszky R; Szabolcs Zs; Köteles F Ideggyogy Sz 2019;72(9-10):337-341.

Célkitúzés - A modernkori egészségféltés a negatív affektivitás indikátoraihoz, összeesküvés-elméletekhez és paranormális hiedelmekhez is kapcsolódik egészséges személyekben.

Kérdésfeltevés - A pilot vizsgálat célja a modernkori egészségféltés és a negatív affektivitás indikátorainak felmérése volt pszichiátriai betegek körében. Emellett a modernkori egészségféltés és a paranoid és szkizofrén tendenciák kapcsolatának felderítése is célunk volt. A vizsgálat módszere - Keresztmetszeti kérdőíves vizsgálat.

A vizsgálat alanyai - Szorongásos és/vagy hangulatzavarral diagnosztizált betegek $(n=66)$.

Eredmény - A pszichiátriai betegek a szomatikus betegeknél magasabb fokú modernkori egészségféltéssel, szomatoszenzoros amplifikációs tendenciával és egészségszorongással jellemezhetők. A modernkori egészségféltés közepes erősségú kapcsolatot mutatott a paranoid $(r=0,35, p<0,01)$ és a szkizofrén $(r=0,37$, $p<0,01)$ tendenciákkal. A többszörös lineáris regressziós elemzésben a szomatoszenzoros amplifikáció $(\beta=0,452$, $p<0,001)$ és a paranoia $(\beta=0,281, p<0.01)$ járult hozzá szignifikáns mértékben a modernkori egészségféltéshez $\left(R^{2}=0,323, p<0,001\right)$.

Következtetés - A szorongásos és/vagy hangulatzavarral diagnosztizált betegekre fokozott mértékú egészségféltés, egészségszorongás és szomatoszenzoros amplifikáció jellemző. A modernkori egészségféltéshez paranoid tendencia kapcsolódik.

Kulcsszavak: negatív affektivitás, modernkori egészségféltés, szorongás, depresszió, paranoia

Correspondent: Ferenc KÖTELES, Institute of Health Promotion and Sport Sciences, Eötvös Loránd University;

1117 Budapest, Bogdánfy Ödön u. 10. E-mail: koteles.ferenc@ppk.elte.hu https://orcid.org/0000-0001-5460-5759

Érkezett: 2018. július 9. Elfogadva: 2018. október 2. 
$\mathrm{M}$ odern health worries (MHWs), the worries about possible harmful effects of modern life and technologies (e.g. traffic fumes, food additives, mobile phones), are increasing in the developed countries ${ }^{1}$. They are associated with a variety of subjective symptoms, worse perceived health status, self-certified sick leave, depression, and increased utilization of health care services ${ }^{1-4}$. Concerning trait-like personality characteristics, associations with negative affect, somatosensory amplification, and health anxiety were reported ${ }^{1,3,5-7}$. Based on these findings, it was concluded that somatic symptoms distress (i.e. illness) represents a major factor behind $\mathrm{MHWs}^{7}$. In accordance with the aforementioned findings, elevated levels of MHWs were reported in people with idiopathic environmental intolerances (IEIs), e.g., multiple chemical sensitivity or electromagnetic hypersensitivity ${ }^{8,9}$. To date, no systematic research has been carried out in patients with affective disorders, who are characterized by chronic symptoms and conditions that also belong to the umbrella term negative affect ${ }^{10}$.

Another line of empirical research revealed that MHWs were also associated with holistic thinking ${ }^{7}$, spirituality $^{11}$, intuitive-experiential thinking style ${ }^{11}$, paranormal beliefs ${ }^{12}$, a negative attitude towards science $^{13}$, and medical conspiracy theories ${ }^{14}$. From a clinical point of view, these phenomena, although do not necessarily reach the pathological level, might refer to psychotic-delusional, or, using a dimensional approach, schizotypa $\mathrm{l}^{11}$ and paranoid ${ }^{14}$ tendencies. In past research, these tendencies were assessed using various attitude scales and questionnaires developed to measure individual differences dominantly within the healthy domain. Results obtained with instruments designed to directly measure these constructs within the pathological domain would considerable extend our current knowledge concerning the background of MHWs.

In the present pilot study, it was expected that (1) MHWs, (2) somatic symptoms, (3) somatosensory amplification, and (4) health anxiety would be relatively increased among patients with affective disorders. We also assumed a positive association between MHWs and (5) schizotypal and (6) paranoid tendencies.

\section{Method}

\section{PARTICIPANTS}

Participants were psychiatric patients with a diagnosis of DSM-IV Axis I mood or anxiety disorder (in terms of ICD-10: mood/affective disorders, F30-39 or neurotic, stress related and somatoform disorders, F40-49) without psychotic symptoms. During the study period (9 months), all patients who were directed to the psychiatric department of the hospital and belonged to one of the aforementioned diagnostic categories were asked to participate. No data on substance use, severity, findings of subsequent diagnostic procedures, and medication are available. Participants completed the questionnaires on their own along with other diagnostic tests in the hospital. They received the information that the questionnaires assess health related worries and the results do not impact their diagnosis and treatment. Five patients $(6.9 \%)$ refused participation in the study. Out of the 68 data set obtained, two was excluded due to missing data. The final data-set consists of 66 patients (77.3\% female; age: $20-65$ yrs, $\mathrm{M}=44.1, \mathrm{SD}=12.12$ yrs; educational qualification: $33.8 \%$ elementary school, $49.2 \%$ high school, $16.9 \%$ university level). The study was approved by the Research Ethical Committee of the university (2011/38/2) and the hospital (0/158-0/2011). Participants signed an informed consent form before completing the questionnaires.

\section{QUESTIONNAIRES}

Somatosensory Amplification Scale (SSAS) ${ }^{15}, 16$ assesses the tendency to experience somatic sensation as intense, noxious, and disturbing. The SSAS consists of 10 items that are rated on a 5-point Likert scale (1: not at all ... 5: extremely). Higher scores refer to higher levels of amplification tendency. Internal consistency of the scale was 0.700 in the present study.

Patient Health Questionnaire Somatic Symptom Severity Scale (PHQ-15) ${ }^{17}$ is a 15 -item scale designed to measure how disturbing the most common somatic symptoms (e.g. headache, nausea) were in the last 4 weeks on a 3-point Likert scale (0: not bothered at all ... 2: bothered a lot). Cronbach's $\alpha$ coefficient in the current study was 0.860 .

The Short version of the Health Anxiety Inventory (SHAI) ${ }^{18,19}$ measures the fear of having a serious illness independently of actual physical health status with 18 items on a 4-point scale. Higher scores refer to higher levels of health anxiety. Cronbach's $\alpha$ coefficient was 0.860 in the present study.

Modern Health Worries Scale (MHWS) ${ }^{1,20}$ is a 25-item scale that measures people's concerns of modernity (e.g. amalgam dental fillings, overuse of antibiotics, electromagnetic radiation) affecting their health. Items are rated on a 5-point Likert scale (1: not at all ... 5: extremely). Higher scores indicate more worries. In the present study, the internal consistency of the Hungarian version was 0.951 . 
Table 1. Descriptive statistics (means and standard deviations) and results of pair-wise comparisons

\begin{tabular}{|c|c|c|c|c|c|c|}
\hline & $\begin{array}{l}\text { Psychiatric patients } \\
(\mathrm{n}=66)\end{array}$ & Somatic outpatients & $\dagger$ & $\mathrm{p}$ & Cohen's d & $\eta^{2}$ \\
\hline $\begin{array}{l}\text { Somatosensory } \\
\text { amplification }\end{array}$ & $30.15 \pm 6.412$ & $27.22 \pm 7.34616(n=562)$ & 3.104 & 0.002 & 0.425 & 0.0432 \\
\hline $\begin{array}{l}\text { Subjective somatic } \\
\text { symptoms }\end{array}$ & $16.86 \pm 5.971$ & $9.10 \pm 5.69416(n=562)$ & 10.420 & $<0.001$ & 1.330 & 0.3066 \\
\hline Health anxiety & $43.97 \pm 9.174$ & $34.16 \pm 7.5793(n=180)$ & 8.485 & $<0.001$ & 1.166 & 0.2537 \\
\hline $\begin{array}{l}\text { Modern health } \\
\text { worries }\end{array}$ & $74.85 \pm 20.262$ & $68.07 \pm 22.5183(n=180)$ & 2.148 & 0.033 & 0.317 & 0.0245 \\
\hline Paranoia & $65.39 \pm 11.670$ & - & - & - & - & - \\
\hline Schizophrenia & $66.76 \pm 14.143$ & _- & _- & _- & _- & _- \\
\hline
\end{tabular}

Table 2. Pearson-correlations between the assessed variables

\begin{tabular}{|llllll|}
\hline $\mathrm{N}=66$ & SSAS & PHQ-15 & SHAl & Paranoia & Schizophrenia \\
\hline Modern health worries & $0.50^{* * *}$ & $0.44^{* * *}$ & $0.28^{*}$ & $0.35^{* *}$ & $0.37^{* *}$ \\
Somatosensory amplification (SSAS) & - & $0.42^{* * *}$ & $0.37^{* *}$ & 0.15 & $0.24^{*}$ \\
Subjective somatic symptoms (PHQ-15) & - & - & $0.36^{* *}$ & $0.37^{* *}$ & $0.46^{* * *}$ \\
Health anxiety (SHAI) & - & - & - & 0.16 & $0.36^{* *}$ \\
Paranoia & - & - & - & - & $0.76^{* * *}$ \\
\hline
\end{tabular}

The Paranoia $(\mathrm{Pa})$ scale of the Minnesota Multiphasic Personality Inventory (MMPI) ${ }^{21}$ was used to assess paranoid tendencies, e.g. , suspiciousness, general distrust of others, and false accusations.

The Schizophrenia (Sc) scale of the MMPI measures the propensity to delusions, diffuse or bizarre thoughts, and social alienation.

\section{STATISTICAL ANALYSIS}

Data was analyzed using the SPSS v20 software. For SSAS, PHQ-15, SHAI, and MHWS scores, patients' data was compared to data obtained from patients visiting their general practitioners $(\mathrm{GPs})^{3,16}$ using Student t-test. Associations between the assessed variables were estimated with Pearson correlation. Finally, a multiple linear regression analysis was carried out with MHWS score as criterion variable; predictor variables (SSAS, PHQ-15, SHAI, MHWS, MMPI-Pa, MMPI-Sc) were entered using the STEPWISE method.

\section{Results}

Descriptive statistics and results of t-tests are presented in Table 1. Psychiatric patients showed higher scores than somatic patients with respect to all four constructs, with small-medium (somatosensory amplification, MHWs) or large (somatic symptoms, health anxiety) effect size. Concerning paranoid and schizophrenic tendencies, psychiatric patients showed elevated but not extremely high $\mathrm{T}$ scores.

Correlation analysis indicated weak to medium level positive associations between MHWS, and PHQ-15, SHAI, and SSAS scores. Similarly, MHWS were positively associated with the Paranoia and Schizophrenia scales of MMPI (medium level associations; for details, see Table 2).

In the first step of the multiple linear regression analysis $\left(\mathrm{R}^{2}=0.246, \mathrm{p}<0.001\right)$, SSAS score was entered in the equation $(\beta=0.496, p<0.001)$. The second step $\left(\mathrm{R}^{2}=0.323, \mathrm{p}<0.001\right)$ indicated the significant contribution of MMPI-Pa $(\beta=0.281$, $\mathrm{p}=0.009)$ beyond SSAS $(\beta=0.452, \mathrm{p}<0.001)$.

\section{Discussion}

Psychiatric patients diagnosed with DSM-IV Axis I mood and/or anxiety disorder showed higher levels of modern health worries, subjective somatic symptoms, health anxiety, and somatosensory amplification than patients visiting their GPs. As these psychiatric conditions are characterized by high levels of negative affect ${ }^{10}$, and the four assessed constructs are also associated with negative affect $^{3,22}$, these findings demonstrate that negative affect (i.e. anxiety, depression) has a general impact on psychological functioning, influencing a variety of cognitive- 
emotional processes ${ }^{23}$. From a cognitive point of view, high (pathological) level negative affect leads to marked cognitive distortions such as catastrophisation tendency and externalizing attribution style which increase the four aforementioned characteristics. The weak to medium level associations between the four constructs also support this view. Moreover, no association between MHWs and negative affect was found in healthy participants in several studies ${ }^{9,24}$, thus the finding that MHWs are increased in individuals with high level of negative affect represent an important contribution to the literature. Of course, the above mentioned cognitive distortions might directly contribute to the worrying tendency and increase MHWs.

The current study replicates the already reported ${ }^{3,5-7}$ connections between MHWs and somatosensory amplification, health anxiety, and somatic symptoms in a clinical sample. However, the associations with schizophrenic and paranoid tendencies are novel, as these connections have not been assessed with clinical instruments to date. As the contribution of paranoia remained significant even after partialling out the effect of somatosensory amplification, it might represent an important feature of MHWs. Among patients with idiopathic environmental intolerances (e.g. multiple chemical sensitivity or electromagnetic hypersensitivity), a high prevalence of psychiatric disorders (usually somatoform disorders, affective and anxiety disorders, impacting 36-100\% of patients) is reported ${ }^{25,26}$. In a German study, however, 18 of 120 patients with environmental illness were diagnosed with paranoid hallucinatory psychosis $^{27}$, and paranoid ideation tendency was increased in another study as well ${ }^{26}$. Elevated schizophrenia scores in patients with multiple chemical sensitivity were also reported ${ }^{28}$. Generally, environmental illnesses are characterized by a strong and fixed belief, or overvalued idea, concerning the cause of the complaints, that is practically impossible to change through logical reasoning and empirical evidence ${ }^{29}$. As persecutory delusions (i.e. threat beliefs) are among the most frequently occurring delusions and symptoms of psychosis ${ }^{30}$, the association between paranoid tendencies and modern health worries appears logical. Paranoid thinking style is characterized by dissociation and externalization of dangerous or even unpleasant contents, hypervigilance to possible threats, malignancy, and distortion of reality to justify assumed associations and external threats. High level of perceived threat posed by modern environmental factors fits very well in this worldview.

Findings of the current study support the view that the MHWs phenomenon can not be regarded as a pure manifestation of negative affect ${ }^{11,22}$. A further, independent dimension beyond illness distress also plays a role. This dimension is characterized primarily by holistic thinking and spirituality, i.e., indicators of intuitive-experiential information processing style $^{11}$. However, paranoid tendencies, e.g. false accusations (mistaken attribution and distrust) and a general suspiciousness appear to be involved as well. These tendencies, interacting with the usually exaggerated media reports on the risk posed by various environmental factors ${ }^{1}$, may considerably increase individuals' vulnerability to MHWs. In the treatment of patients with idiopathic environmental illness, health professionals should take into account possible paranoid tendencies. Beyond their contribution to the illness, these also might reduce compliance and confidence in traditional medical approaches.

The current study is not without limitations. First, it is a cross-sectional pilot study conducted in a nonrepresentative and relatively small patient sample, primarily with explorative goals. Therefore, a number of potential confounders might have impacted the results, thus they might not be comparable with those obtained in other studies. Second, scales from the first version of the MMPI were used, although a revised version is available. Third, the control samples were obtained from different populations which makes the results of the group-wise comparisons questionable. To draw a final conclusion, replication of the reported findings in more homogeneous and more precisely defined samples using a more recent instrument for the assessment of pathological tendencies would be necessary.

\section{Conclusion}

Patients with affective disorders are characterized by higher levels of modern health worries, health anxiety, and somatosensory amplification. Modern health worries are associated with paranoid tendencies. The identification of paranoid tendencies might be relevant for the treatment of psychiatric patients exhibiting MHWs.

\section{ACKNOWLEDGEMENTS}

This research was supported by the Hungarian National Scientific Research Fund (K 109549, K 124132) and the János Bolyai Research Scholarship of the Hungarian Academy of Sciences (for $R$. Szemerszky). Péter Simor was supported by the Hungarian Scientific Research Fund (NKFI PD 115432) of the National Research, Development and Innovation Office.

DECLARATION OF INTEREST: None. 


\section{REFERENCES}

1. Petrie KJ, Sivertsen B, Hysing $M$, et al. Thoroughly modern worries: the relationship of worries about modernity to reported symptoms, health and medical care utilization. J Psychosom Res 2001;51:395-401. https://doi.org/10.1016/s0022-3999(01)00219-7

2. Indregard A-MR, Ihlebaek CM, Eriksen HR. Modern health worries, subjective health complaints, health care utilization, and sick leave in the norwegian working population. Int J Behav Med 2013;20:371-377. https://doi.org/10.1007/s12529-012-9246-1

3. Köteles F, Simor P. Modern health worries, somatosensory amplification, health anxiety, and well-being. A Cross-sectional Study. Eur J Mental Health 2014;9:20-33.

https://doi.org/10.5708/ejmh.9.2014.1.2

4. Rief W, Glaesmer H, Baehr V, Broadbent E, Brähler E, Petrie KJ. The relationship of modern health worries to depression, symptom reporting and quality of life in a general population survey. J Psychosom Res 2012;72:318-20. https://doi.org/10.1016/j.jpsychores.2011.11.017

5. Andersen JH, Jensen JC. Modern health worries and visits to the general practitioner in a general population sample: An 18 month follow-up study. Journal of Psychosomatic Research 2012;73:264-7. https://doi.org/10.1016/j.jpsychores.2012.07.007

6. Filipkowski KB, Smyth JM, Rutchick AM, et al. Do healthy people worry? Modern health worries, subjective health complaints, perceived health, and health care utilization. Int J Behav Med 2010;17:182-8. https://doi.org/10.1007/s12529-009-9058-0

7. Köteles $F$, Simor P. Illness and holistic thinking as major dimensions behind modern health worries. International Journal of Behavioral Medicine. 2014; in Press. https://doi.org/10.1007/s12529-013-9363-5

8. Bailer J, Witthöft M, Rist F. Modern health worries and idiopathic environmental intolerance. J Psychosom Res 2008;65: 425-33. https://doi.org/10.1016/j.jpsychores.2008.05.006

9. Dömötör Z, Doering BK, Köteles F. Dispositional aspects of body focus and idiopathic environmental intolerance attributed to electromagnetic fields (IEI-EMF). Scand J Psychol 2016;57:136-43. https://doi.org/10.1111/sjop.12271

10. Watson D, Clark LA. Negative affectivity: the disposition to experience aversive emotional states. Psychol Bull 1984;96: 465-90. https://doi.org/10.1037//0033-2909.96.3.465

11. Köteles $F$, Simor P, Czetö $M$, Sárog $N$, Szemerszky $R$. Modern health worries - the dark side of spirituality? Scand J Psychol 2016;57:313-20. https://doi.org/10.1111/sjop.12297

12. Jeswani M, Furnham A. Are modern health worries, environmental concerns, or paranormal beliefs associated with perceptions of the effectiveness of complementary and alternative medicine? Br J Health Psychol 2010;15:599-609. https://doi.org/10.1348/135910709x477511

13. Furnham A. Are modern health worries, personality and attitudes to science associated with the use of complementary and alternative medicine? Br J Health Psychol 2007; 12:229-43. https://doi.org/10.1348/135910706x100593

14. Lahrach Y, Furnham A. Are modern health worries associated with medical conspiracy theories? Journal of Psychosomatic Research 2017;99:89-94.

https://doi.org/10.1016/j.jpsychores.2017.06.004

15. Barsky AJ, Wyshak G, Klerman GL. The Somatosensory Amplification Scale and its relationship to hypochondriasis. J Psy Res 1990;24:323-34. https://doi.org/10.1016/0022-3956(90)90004-a
16. Köteles F, Gémes H, Papp G, et al. A Szomatoszenzoros Amplifikáció Skála (SSAS) magyar változatának validálása. Mentálhigiéné és Pszichoszomatika 2009;10:321-35. https://doi.org/10.1556/0406.18.2017.014

17. Kroenke K, Spitzer RL, Williams JBW. The PHQ-15: validity of a new measure for evaluating the severity of somatic symptoms. Psychosom Med 2002;64:258-66. https://doi.org/10.1097/00006842-200203000-00008

18. Köteles $F$, Simor P, Bárdos G. A Rövidített Egészségszorongás Kérdőív (SHAI) magyar verziójának kérdőíves validálása és pszichometriai értékelése. Mentálhigiéné és Pszichoszomatika 2011;12:191-213. https://doi.org/10.1556/0406.18.2017.014

19. Salkovskis PM, Rimes KA, Warwick HMC, Clark DM. The Health Anxiety Inventory: development and validation of scales for the measurement of health anxiety and hypochondriasis. Psychol Med 2002;32:843-53. https://doi.org/10.1017/s0033291702005822

20. Köteles F, Szemerszky R, Freyler A, Bárdos G. Somatosensory amplification as a possible source of subjective symptoms behind modern health worries. Scand J Psychol 2011;52:174-8. https://doi.org/10.1111/j.1467-9450.2010.00846.x

21. Hathaway SR, McKinley JC. The Minnesota Multiphasic Personality Schedule. Minneapolis, MN, US: University of Minnesota Press; 1942.

22. Köteles F, Simor P. Somatic symptoms and holistic thinking as major dimensions behind modern health worries. IntJ Behav Med 2014;21:869-76. https://doi.org/10.1007/s12529-013-9363-5

23. Watson D, Pennebaker JW. Health complaints, stress, and distress: exploring the central role of negative affectivity. Psychol Rev 1989;96:234-54. https://doi.org/10.1037//0033-295x.96.2.234

24. Witthöft M, Freitag I, Nußbaum C, et al. On the origin of worries about modern health hazards: Experimental evidence for a conjoint influence of media reports and personality traits. Psychol Health Epub 2017 Jul 31::1-20. https://doi.org/10.1080/08870446.2017.1357814

25. Bornschein S, Förstl H, Zilker T. Idiopathic environmental intolerances (formerly multiple chemical sensitivity) psychiatric perspectives. J Intern Med 2001;250:309-21. https://doi.org/10.1046/j.1365-2796.2001.00870.x

26. Bornschein S, Hausteiner C, Konrad F, Förstl H, Zilker T. Psychiatric morbidity and toxic burden in patients with environmental illness: a controlled study. Psychosom Med 2006;68:104-9. https://doi.org/10.1097/01.psy.0000195723.38991.bf

27. Köppel C, Fahron G. Toxicological and neuropsychological findings in patients presenting to an environmental toxicology service. J Toxicol Clin Toxicol 1995;33:625-9. https://doi.org/10.3109/15563659509010619

28. Fiedler N, Kipen HM, DeLuca J, Kelly-McNeil K, Natelson $B$. A controlled comparison of multiple chemical sensitivities and chronic fatigue syndrome. Psychosom Med 1996; 58:38-49. https://doi.org/10.1097/00006842-199601000-00007

29. Henningsen $P$, Priebe S. New environmental illnesses: what are their characteristics? Psychother Psychosom 2003; 72:231-4. https://doi.org/10.1159/000071893

30. Freeman D, Garety PA, Kuipers E, Fowler D, Bebbington $P E$. A cognitive model of persecutory delusions. British Journal of Clinical Psychology 2002;41:331-47. https://doi.org/10.1348/014466502760387461 